\title{
$\left(\int_{\text {PSSR }}\right.$ \\ Pakistan Social Sciences Review www.pssr.org.pk
}

\section{RESEARCH PAPER}

\section{Impact of Cognitive Dissonance Bias on Investors' Decisions: Moderating Role of Emotional Intelligence}

\author{
Nagina Jamil * ${ }_{1}$ Dr. Taqadus Bashir ${ }^{2}$
}

1. Ph. D Scholar, Management Sciences Department, Bahria University, Islamabad, Pakistan

2. Professor, Management Sciences Department, Bahria University, Islamabad, Pakistan

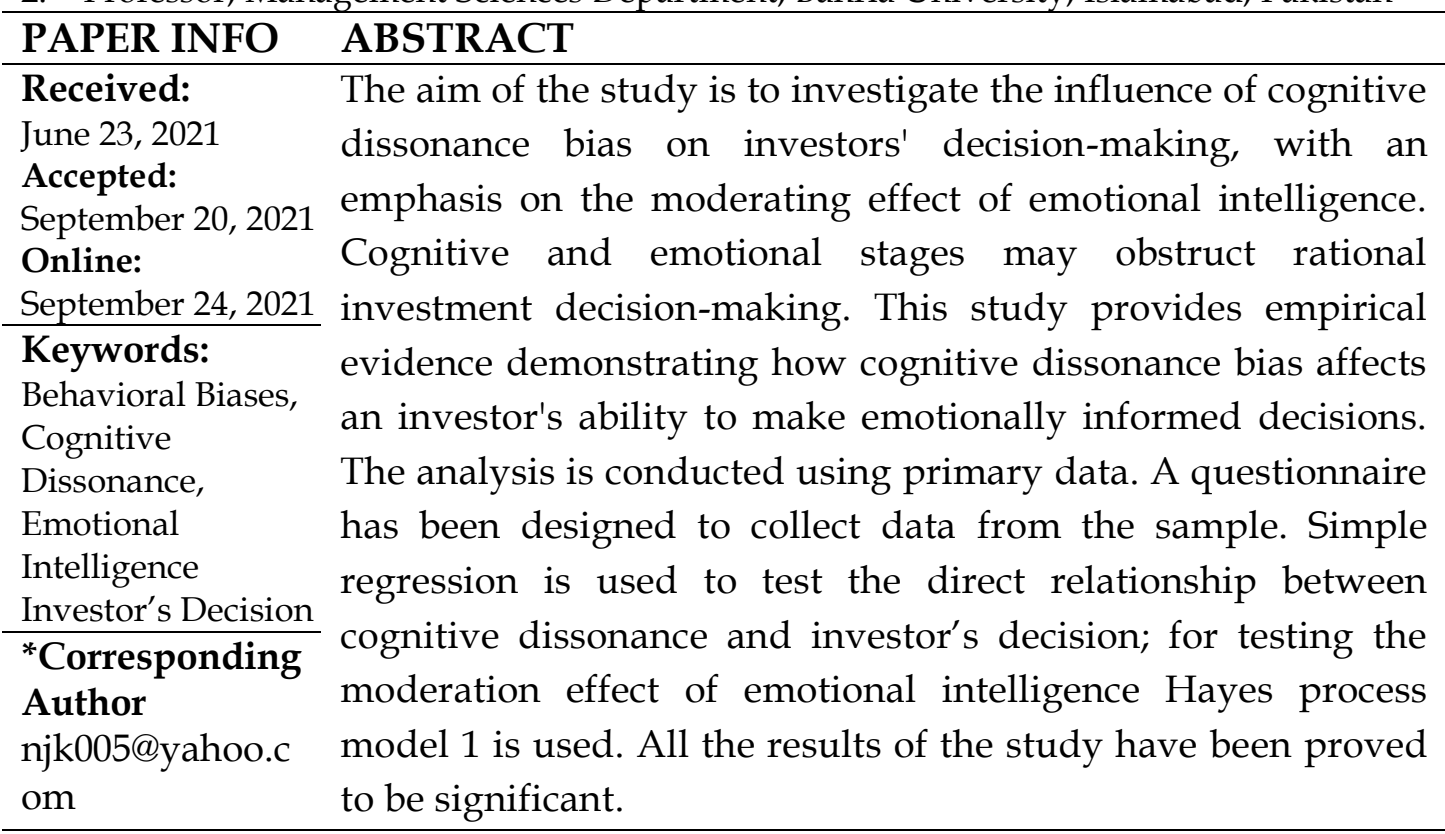

\section{Introduction}

The economic paradigm in traditional finance assumes that investors behave rationally, i.e., they tend to maximize their expected utility from the available alternatives, they select the best optimal portfolio with the expected returns as a function of risk (Markowitz, 1952) and market is efficient, also known as an efficient market hypothesis $(\mathrm{EMH})$, i.e., market prices of the securities are reflecting all available information in the market (Fama 1970). However, evidence shows that investors' behavior does not match such models, and that rationality is a myth owing to some cognitive and emotional errors that impair a person's ability to make completely rational decisions (Bukhari et al, 2006). Shleifer and Summers (1990) discussed how noise traders react to incomplete information, causing a difference between the security prices and their intrinsic value, which shows that security prices not only respond to available information but also to other factors that are not fully justified by the information, i.e., changes in sentiments or expectations. Such behavior 
of noise traders has shown unrealistic properties of efficient market hypotheses and the presence of market anomalies.

Investment decision making is a cognitive process of choosing the best option (Bhatia et al., 2020). Investors do not always have the same information, nor do they always analyze it the same way, resulting in poor or inconsistent investing decisions (Babajide \& Adetiloy, 2012; Toma, 2015). Perceived fairness of an investment offer influences investor decision-making (Sanfey et al., 2003). Behavioral biases, which are not addressed in conventional finance, are the primary cause of such conduct. Understanding behavioral biases may help investors make more profits (CFA, 2019). Investors' emotions and psychology (Kahneman \& Tversky, 1979) influence their choices, causing a bias, which is why investors act irrationally (Zaidi \& Tauni, 2012). Shefrin (2007) defined biases as the predispositions toward error. Thus, a bias is a propensity to take decisions based on an underlying belief. In behavioural finance, Behavioral biases help explain investors' irrational behavior (Kahneman \& Riepe, 1998). Due to their inability to interpret complete information, investors are prone to biases, mistakes, and illusions (Shefrin, 2010). Notably, erroneous investment decisions may be influenced by a variety of behavioral biases (Bhatia et al., 2020).

Emotional intelligence is one's ability to recognize their own and others' emotions, classify them, and utilize them in productive thinking and behavior. Emotions have an essential part in decision making, reasoning, and social relationships. Emotionally intelligent people have a more optimistic perspective on challenging situations, which leads to better decisions (Gardner \& Stough, 2002). Emotions may be used to your advantage, so utilize them well. The key is to understand how to utilize your emotions in a profitable way (Ameriks et al., 2009). Emotional intelligence is a major predictor of optimum investment choices and is regarded as a vital tool in increasing individual efficacy in interacting with participants (Quinn \& Wilemon, 2009). Emotional intelligence, along with investor psychology, helps them to regulate their emotional perception and understanding of their emotions (Lu, Bai, \& Wang, 2011), which are vital psychological factors for an optimal investment decision. Even though evaluation of investment properties has received considerable attention, to date, academic research on behavioral drivers has been limited (Gurdgiev \& O'Loughlin, 2020).

The aim of the study is to investigate the influence of cognitive dissonance bias on investors' decision-making, with an emphasis on the moderating effect of emotional intelligence. Cognitive and emotional stages may obstruct rational investment decision-making. This study provides empirical evidence demonstrating how cognitive dissonance bias affects an investor's ability to make emotionally informed decisions.

\section{Literature Review}

Studies have documented investor irrationality i.e. (Barber \& Odean, 2000; 2001; 2008; French \& Poterba, 1991; Ivkovic \& Weisbenner, 2005; Statman et al., 2006 
among others). The issue of how investors make investment decisions is examined by a variety of survey research. Several empirical studies in behavioral finance (French \& Poterba, 1991; Odean, 1998; Barber \& Odean, 2000; Bailey et al., 2011) demonstrate that investors are susceptible to a variety of behavioral biases.

The cognitive process of decision making includes the selection of one alternative out of several alternative courses of actions. Many stock market investors lack proper understanding of the fundamental economics concepts that are required for making investment decisions. As a result, more research is required for the factors which may influence decisions regarding the investment (Lusardi \& Mitchell, 2006).Cognitive biases are psychological phenomena that describe an individual's ideas, values, thoughts, and attitudes that arise from faulty reasoning and illogical judgments. It includes biases like overconfidence, anchoring and adjustment, representativeness, framing, cognitive dissonance, mental accounting, availability and self-attribution bias, among others (Pompian, 2006). Cognitive biases are mostly the result of faulty reasoning and may be addressed by improved knowledge, information, and guidance. As a result, cognitive errors can be reduced to a significant degree, if not removed entirely, in the investment decision-making process (Bankole1, 2019).

Cognitive dissonance occurs when new information contradicts prior beliefs, or when two opposing ideas exist in one's mind. The idea of cognitive dissonance was first proposed by Festinger (1957). Cognitive dissonance bias is associated with a psychologically unpleasant condition and may result in cognitive errors, incorrect judgments, and incorrect reasoning (Evans, 1983). Goetzmann (1997) discussed investors' cognitive dissonance when they continue to retain a failing investment fund. Due to the fact that some forms of cognitive bias have a direct effect on investors' risk perceptions and how they deal with risks associated with their choices, there is increasing interest in determining whether and how individual cognitive bias influences them (Simon et al., 2000). Pompian (2006) also defines Cognitive dissonance is a psychological phenomenon that arises when newly acquired information contradicts already existing beliefs and understandings, resulting in the mental discomfort that arises from this contradiction. Some researchers are of the view that having cognitive dissonance bias leads investors towards confirmations and overconfidence bias. According to Olsen (2008), when investors refuse to modify their views on stock performance, it leads to negative outcomes and increases their degree of discomfort. At this point, they become overconfident and While constantly looking for methods to confirm their opinion, they suffer from confirmation bias (Kanojia et al., 2018), which confirms that Indian investors are surfing from cognitive dissonance leading them towards irrational decisions. The study also identified that age can affect cognitive dissonance directly. In a theoretical study, Fatima (2019) developed a theoretical framework of cognitive dissonance bias that have an effect on investor's decisions. Empirical studies were used to measure the extent to which investors' behavior deviates from rational decision-making. The study recognized different demographic and emotional factors that increase the cognitive dissonance in investors, which influences their decision making. 
Cognitive dissonance arises when mental discomfort in an investor is due to newly acquired information that leads him to make irrational decisions. Because investors do not admit that their decision was incorrect, but instead blames the circumstances or choices. They do not learn from past experiences and mistakes as they have to acknowledge their bad decisions. However, if they want to rectify their decisions in the future, they take time to correct them. All of these factors lead them towards irrational behavior in decisions.

H1: Investors' decisions are significantly influenced by the presence of cognitive dissonance bias.

A person's emotional intelligence is defined as his ability to identify, classify as well as utilize the emotions to guide their thoughts and actions. Emotional intelligence was introduced by Salovey and Mayer (1990). They defined emotional intelligence as "the capacity to monitor one's own and others' emotions, distinguish between them, and utilize the knowledge to guide one's thoughts and actions". Unlike the other social intelligences, Emotional Intelligence focuses on recognizing and using emotional states of oneself and others in order to solve issues along with behavioral control. Mayer and Salovey (1997) developed a four-branch conceptual ability model of emotional skills. The model described emotional intelligence as the ability to perceive, use, comprehend and manage emotions.

Daniel Goleman (1998) popularized the phrase "emotional intelligence" in his book "Emotional Intelligence: Why It Matters More Than IQ". Self-awareness, Selfregulation, Social skills, Empathy, and Motivation are all components of Goleman's (1998) Emotional Intelligence model. This approach is used to educate and assess managerial potentials and abilities. Emotional intelligence is the ability to recognize one's own and others' emotions and employ them to solve problems (Schutte et al., 1998), as well as the capacity to recognize the elements; how they vary, and thus perceive about emotions (Mayer, Caruso, \& Salovey, 1999). Boyatzis et al. (2000) also promoted the idea of Emotional Intelligence and described as the capacity and aptitude to cope with one's feelings and emotions. Emotional intelligence consists of three distinct components: the assessment and appearance of emotions, the emotional regulation, and the implementation of emotional information in thought process and actions (Petrides \& Furnham, 2000). The ability to recognize emotions is indeed a critical component of emotional intelligence, since it aids in predicting social success (Zee, Thijs, \& Schakel, 2002). Different investors see and interpret the same information in different ways. These Distinct interpretations lead to diverse perceptions of same information, resulting in different behaviors'. Consequently such behaviors' effects the on investor decisions (Sanglier et al., 1996). Past researches suggest that role of one's emotions in decision making, thinking, and social relationship is important. Emotionally intelligent individuals have more positive outlook towards difficult situations that gives progressive solutions as it boosts their confidence (Gardner \& Stough, 2002) that lead to effective decisions (Scott, Ladd \& Chan, 2004). The reliability of investors' decisions lies in the effectiveness of their 
investment return strategy (Rutkauskas \& Stasytyte, 2008). While no one knows the long-term dynamics of markets, it is not essential that investors act rationally at all stages of the decision-making process (Scalliet, Karoui, Jeanblanc, \& Martellini, 2008). Investors perform better when they manage and regulate their emotional reactions and they might even find their own emotions a better information source than the anticipated market condition (Fenton-O'Creery et al., 2011). Lashgari, (2015) declared that investors want to increase their returns, reduce their losses and to minimize regret from their decisions that is only possible by understanding, managing and regulating their emotions. He came to the conclusion that modern portfolio theory, investment psychology, and neuroscience findings may all work together to improve decision making.

Bouzguenda (2018) presented a complex decision process that involved the overlapping of several individual as well as internal and external factors and declared that emotions are supposed to raise awareness in self as well as others and are considered as a mechanism for regulation with a reorganizing action for a "satisfying" solution.

Because Emotional Intelligence is a person's capacity to recognize and manage emotions in one and others, Emotional Intelligence skills may be useful in minimizing the effects of cognitive dissonance bias when applied to individual decision-making. Thus proposing, emotionally intelligent investors are less prone to biases in their decision-making.

H2: Emotional intelligence has a strong moderating effect on the relationship between cognitive dissonance bias and Investor decisions.

\section{Theoretical Framework of the Study}

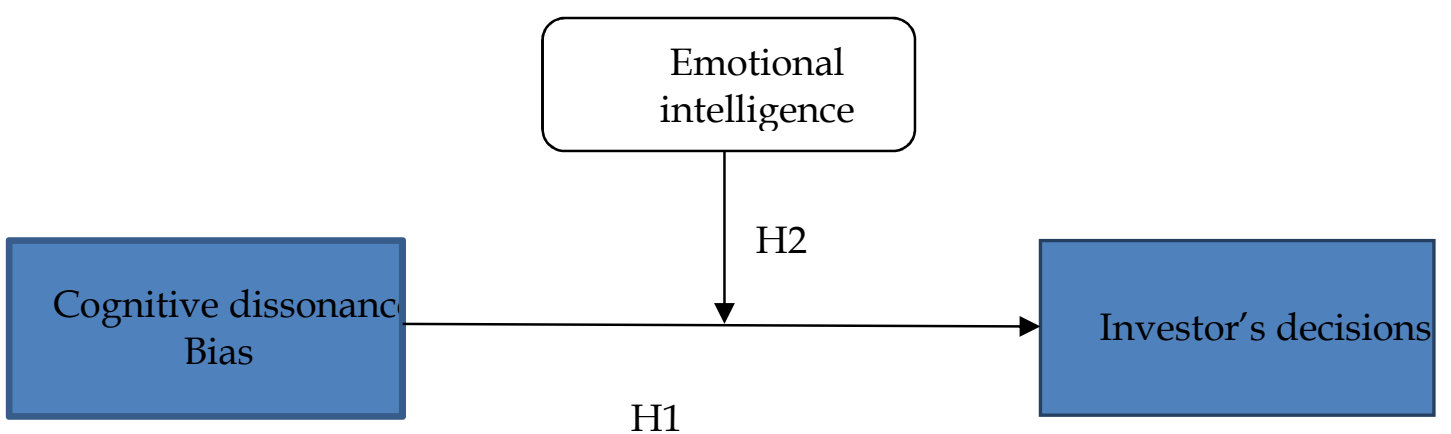

\section{Material and Methods}

The data were collected through adapted questionnaires from different sources. A total, 294 questionnaires were received out of 500 distributed questionnaires using convent sampling, providing a response rate of $58.8 \% .5$ point Likert scale is used to measure response of all items where 5 represents strongly disagree, to 1 represents strongly agree, unless otherwise stated. First part in Questionnaire consists of demographics of the participants, second part of the 
questionnaire consisted of cognitive dissonance bias and third part includes emotional intelligence. Last part of the questionnaire constituted investor's decision.

Table 1

Demographic Characteristics

\begin{tabular}{llllll}
\hline & Frequency & Percent & & Frequency & Percent \\
\hline Gender & & & Experience & \\
\hline Male & 198 & 67.3 & $0-5$ & 149 & 50.7 \\
\hline Female & 96 & 32.7 & $6-10$ & 86 & 29.3 \\
\hline Age & & & $11-15$ & 42 & 14.3 \\
\hline $18-25$ & 65 & 22.1 & $16-20$ & 12 & 4.1 \\
\hline $26-33$ & 124 & 42.2 & $21-25$ & 4 & 1.4 \\
\hline $34-41$ & 75 & 25.5 & Above 25 & 1 & 0.3 \\
\hline $42-49$ & 22 & 7.5 & & & \\
\hline Above 50 & 8 & 2.7 & & & \\
\hline Education & & & & & \\
\hline Matric & 8 & 2.7 & & \\
\hline Inter & 59 & 20.1 & & \\
\hline Bechelor & 66 & 22.4 & & \\
\hline Masters & 129 & 43.9 & & \\
\hline MS/ Mphil & 32 & 10.9 & & \\
\hline
\end{tabular}

Frequency of gender analysis shows that most of the investors were male with a total of 198 from 294 investors, while females were 96 with percentages of 67.3 and 32.7 respectively. The above table states from a total of 294 investors, 194 investors were from age group 26 to 33 years representing $42.2 \%$ where this percentage is slightly higher than the other age brackets. While 75 investors have been reported between 33 to 49 years and 8 investors are above 50 years.

\section{Reliability}

The reliability of the results has been tested for the Data collected from different investors of Pakistan Stock Exchange (PSE). The reliability scores are as follows.

Table 2

Reliability Analysis

\begin{tabular}{lll}
\hline Variable & No. of items & Cronbach's Alpha \\
\hline Cognitive dissonance bias & 10 & .901 \\
\hline Emotional intelligence & 33 & .891 \\
\hline Investor's decision & 11 & .961 \\
\hline
\end{tabular}

Cronbach Alpha Value ranges from 0 to 1 (Antonakis et al., 2003; Rowold, 2005). However, higher values are indicator of greater reliability of the scale. 
According to Field (2013); Sekaran and Bougie (2019) the value of coefficient alpha must be equal to or greater than 0.70 otherwise a variable is not considered reliable. Internal consistencies of scales used are visible in table 2. Cognitive dissonance bias has Cronbach highest value i.e. 0.901 while 0.891 and 0.961 for emotional intelligence and investor's decision respectively. It refers to the high reliabilities of the scale used that are greater than 0.7 .

\section{Model Specification}

$$
\begin{gathered}
\text { ID }=\beta_{0}+\beta_{1} \mathrm{CDB}+\beta_{2} \mathrm{EI}+\epsilon \\
\mathrm{ID}=\beta_{0}+\beta_{1} \mathrm{CDB}+\beta_{2} \mathrm{CDB} * \mathrm{EI}+\epsilon
\end{gathered}
$$

Eq 2

Where;

$\beta_{0}=$ Constant Term, ID = Investor's Decision, $\mathrm{CDB}=$ Cognitive Dissonance Bias, $\mathrm{EI}=$ Emotional intelligence $\mathrm{CDB}^{\star} \mathrm{EI}=$ Moderating Variable $\epsilon=$ Error Term. Eq. 1 measures the direct impact of independent variables on dependent variables while eq. 2 measures the moderation effect with Cognitive Dissonance bias on investor's decision.

\section{Results and Discussion}

\section{Descriptive Statistics}

Table 3

\begin{tabular}{llllll}
\hline & $\mathbf{N}$ & Minimum & Maximum & Mean & Std. Deviation \\
\hline CDB & 294 & 1.00 & 5.00 & 1.8931 & .78820 \\
\hline EI & 294 & 1.00 & 5.00 & 1.7721 & .83025 \\
\hline ID & 294 & 1.00 & 5.00 & 3.4057 & .91550 \\
\hline
\end{tabular}

$\mathrm{CDB}=$ cognitive dissonance bias, $\mathrm{EI}=$ Emotional intelligence, $\mathrm{ID}=$ Investors Decisions

Table 3 display variables name, sample size, maximum and minimum values, mean and standard deviation of the data collected. Mean value of CDB is 1.8931 and standard deviation is 0.78820 which show that most of the investors agreed with the scale items of cognitive dissonance bias. The moderator of this study, emotional intelligence (EI), showed a mean value of 1.7721 with a standard deviation. While the dependent variable, investor's decisions (ID), have a mean of 3.4057 with a standard deviation of.91550. 


\section{Correlation Analysis}

Table 4

\begin{tabular}{llll}
\hline & CDB & EI & ID \\
\hline CDB & 1 & & \\
\hline EI & $.518^{* *}$ & 1 & 1 \\
\hline ID & $.499^{* *}$ & $.359^{* *}$ & \\
\hline
\end{tabular}

Significance level ** at 0.01 and * at 0.05

Table 4 shows the association between the variables of the study. The maximum correlation value between the variables is.518 and all the other correlation values are less than this value that shows all the variable of the study were valid for further data analysis. CDB is significantly positively correlated to EI with .518 correlation value at $1 \%$ level of significance. Similarly the CDB correlates with ID having the value of .499 at $1 \%$ level of significance. EI is also correlated with investor's decision having correlation coefficient values .359, at $1 \%$ significance level.

\section{Regression Analysis}

Table 5

\begin{tabular}{llll}
\hline & B & T & Sig. \\
\hline CDB & -.732 & -5.590 & .000 \\
EI & .102 & 2.200 & .031 \\
\hline $\mathbf{R}^{\mathbf{2}}$ & .386 & &
\end{tabular}

$\mathrm{CDB}=$ cognitive dissonance bias, $\mathrm{EI}=$ Emotional intelligence

Regression analysis is employed to investigate the impact of cognitive dissonance bias and Emotional intelligence on the investor's decisions. According to the results, in table 5 cognitive dissonance bias have a coefficient value of -0.732 that is significant at $1 \%$ level of significance. Results indicate that cognitive dissonance bias negatively but significantly affect the investor's decision which means increase in cognitive dissonance bias among investors will decrease their decision's rationality and vice versa. Thus, supporting the first hypothesis that investors' decisions are significantly influenced by the presence of cognitive dissonance bias. Emotional intelligence is also positively and significantly influencing the investor's decisions. $\mathrm{R}^{2}$ shows that cognitive dissonance bias and Emotional intelligence are explaining 38\% variation in investor's decisions.

\section{Moderation Analysis}

Simple moderation analysis is employed to test the second hypotheses about the paths of casual influence of the cognitive dissonance bias on investor's decisions, through emotional intelligence, the proposed moderator in the study. To calculate this moderation effect moderation model 1 of Hayes (2013) process is used. The model specifies a single moderator where the effect of $\mathrm{X}$ on $\mathrm{Y}$ is conditional to the moderating or interaction variable M's level. In other words Moderating variables change the relationship between $X$ and $Y$ variables either by the strengthening or weakening the 
relationship or by changing the direction of the relationship. The terms interaction and moderation can be used interchangeably because moderation indicates the effect of $X$ on $Y$ at different values of a moderator (Aguinis, Gottfredson, \& Wright, 2011). Hayes process automatically creates an interaction term between the independent and moderating variables $\left(X^{\star} M\right)$.

Table 6

\begin{tabular}{llllll}
\hline Model 1 & B & T & Sig. & LLCI & ULCI \\
\hline CDB & -.703 & -6.5538 & .0000 & -1.3779 & -.7414 \\
\hline EI & .112 & -2.5463 & .0114 & -.9846 & -.1261 \\
\hline Int_1 & .139 & 4.5292 & .0000 & .1921 & .4875 \\
\hline $\mathbf{R}^{2}$ & & .3765 & .0000 & & \\
\hline$\Delta \mathbf{R}^{2}$ & & .0607 & .0000 & & \\
\hline
\end{tabular}

$\mathrm{EI}=$ Emotional intelligence, $\mathrm{CDB}=$ cognitive dissonance bias, $\mathrm{ID}=$ Investors Decisions

The Table 6 indicates results about moderation of emotional intelligence on the relationship between cognitive dissonance bias and investors decisions. The results of demonstrate that the interaction term (Int_1) has the upper and lower limits of .1921 and .4875 and zero is not present in the $95 \%$ confidence interval; p-value is also less than 0.05 indicating it to be significant. Furthermore change in R2 due to emotional intelligence as a moderator comes out to be 0.0607 , with a significant $p$ value. Therefore, we infer that intelligence moderates the relationship between cognitive dissonance bias and investors decisions moderates thus accepting the hypothesis 2 of the study.

\section{Conclusion}

It is concluded from the above results that cognitive dissonance bias is influencing the investor's decisions negatively indicating investors who have high degree of cognitive dissonance bias lack rationality in their decisions. The reason of this negative relation is that investors refuse to acknowledge their faulty decisions rather blame the situational factors, timing or choices. They don't learn from their mistake and don't recognize their poor choices while taking future decisions which leads to irrational decision-making. These results are also supported by Fatima (2019) who proposed a similar theoretical framework for cognitive dissonance bias and Kanojia et al., (2018) confirmed the existence of cognitive dissonance among investors which leads them to irrational decision-making. However incorporating the emotionally intelligent behavior investors can moderate this relationship. Emotional intelligence can help in reducing the level of cognitive dissonance bias among investors as it help individuals to perceive, understand and regulate different emotion in them self and others. Thus Emotional intelligence relieve their mental discomfort arising from contradictory believes and information. And when their cognitive dissonance will be decreased their decisions will be rationalized.

The present study has used only one cognitive bias, future research can be conducted by incorporating more cognitive and emotional biases. Other psychological and social variables like personality, motivation, financial literacy can also be used. 
Furthermore the study is limited to stock market investors only; future research could consider investors from other sectors of economy like real estate or commodity market. 


\section{References}

Aguinis, H, Gottfredson, R. K, \& Wright, T. A. (2011). Best-practice recommendations forestimating interaction effects using meta-analysis. Journal of Organizational Behavior, 32(8), 1033-1043.

Ameriks, J, Wranik, T, \&Salovey, P. (2009). Emotional intelligence and investor behavior.

Antonakis, J, Avolio, B. J, \& Sivasubramaniam, N. (2003). Context and leadership: An examination of the nine-factor full-range leadership theory using the Multifactor Leadership Questionnaire. The leadership quarterly, 14(3), 261-295.

Babajide, A. A, \& Adetiloye, K. A. (2012). Investors' behavioural biases and the security market: An empirical study of the Nigerian security market. Accounting and Finance Research, 1(1), 219-229.

Bailey, W, Kumar, A, \& Ng, D. (2011). Behavioral biases of mutual fund investors. Journal of Financial Economics, 102(1), 1-27.

Barber, B. M, \& Odean, T. (2000). Trading is hazardous to your wealth: The common stock investment performance of individual investors. The journal of Finance, 55(2), 773-806.

Barber, B. M, \& Odean, T. (2008). All that glitters: The effect of attention and news on the buying behavior of individual and institutional investors. The review of financial studies, 21(2), 785-818.

Barber, B. M, \&Odean, T. (2001). Boys will be boys: Gender, overconfidence, and common stock investment. The quarterly journal of economics, 116(1), 261-292.

Bhatia, A, Chandani, A, \& Chhateja, J. (2020). Robo advisory and its potential in addressing the behavioral biases of investors-A qualitative study in Indian context. Journal of Behavioral and Experimental Finance, 25, 100281.

Blanchet-Scalliet, C, El Karoui, N, Jeanblanc, M, \& Martellini, L. (2008). Optimal investment decisions when time-horizon is uncertain. Journal of Mathematical Economics, 44(11), 1100-1113.

Bouzguenda, K. (2018). Emotional intelligence and financial decision making: are we talking about a paradigmatic shift or a change in practices?. Research in international business and finance, 44, 273-284.

Boyatzis, R. E, Goleman, D, \& Rhee, K. (2000). Clustering competence in emotional intelligence: Insights from the Emotional Competence Inventory (ECI). Handbook of emotional intelligence, 99(6), 343-362. 
CFA Institute Curriculum, (2019). Refresher Reading, The Behavioral Biases of Individuals, CFA Program Level III Economics,

Evans, J. S. B, Barston, J. L, \& Pollard, P. (1983). On the conflict between logic and belief in syllogistic reasoning. Memory $\mathcal{E}$ cognition, 11(3), 295-306.

Fama, E. F. (1970). Efficient capital markets: A review of theory and empirical work. The journal of Finance, 25(2), 383-417.

Fatima, A. (2019). Cognitive dissonance and investors' decision-making: A review. International Journal of Financial, Accounting, and Management, 1(1), 39-45.

Fenton-O'Creevy, M, Soane, E, Nicholson, N, \& Willman, P. (2011). Thinking, feeling and deciding: The influence of emotions on the decision making and performance of traders. Journal of Organizational Behavior, 32(8), 1044-1061.

Festinger, L. (1957). A theory of cognitive dissonance (Vol. 2). Stanford university press.

Field, A. (2013). Discovering statistics using IBM SPSS statistics. sage.

French, K. R, \& Poterba, J. M. (1991). Investor diversification and international equity markets. The American Economic Review, 81(2), 222-226.

Gardner, L, \& Stough, C. (2002). Examining the relationship between leadership and emotional intelligence in senior level managers. Leadership $\mathcal{E}$ organization development journal.

Goetzmann, W. N, \& Peles, N. (1997). Cognitive dissonance and mutual fund investors. Journal of financial Research, 20(2), 145-158.

Goleman, D. (1998). Working with emotional intelligence: Why it matters more than IQ. London, UK: Bloomsbury.

Gurdgiev, C, \& O'Loughlin, D. (2020). Herding and anchoring in cryptocurrency markets: Investor reaction to fear and uncertainty. Journal of Behavioral and Experimental Finance, 25, 100271.

Hayes, A. F, \& Preacher, K. J. (2013). Conditional process modeling: Using structural equation modeling to examine contingent causal processes.

Ivković, Z, \& Weisbenner, S. (2005). Local does as local is: Information content of the geography of individual investors' common stock investments. The Journal of Finance, 60(1), 267-306.

Kahneman, D. (1979). Prospect theory: An analysis of decisions under risk. Econometrica, 47, 278. 
Kahneman, D, \& Riepe, M. W. (1998). Aspects of investor psychology. Journal of portfolio management, 24(4), 52.

Kanojia, S, Singh, D, \& Goswami, A. (2018). An empirical analysis of the factors influencing individual investors in the Indian Stock market. Journal of Business and Management, 20(3), 30-37.

Lashgari, M. (2015). Decision making under uncertainty the impacts of emotional intelligence and behavioral patterns. Academy of Accounting and Financial Studies Journal, 19(2), 159.Linnenluecke, M. K, Chen, X, Ling, X, Smith, T, \& Zhu, Y. (2017). Research in finance: A review of influential publications and a research agenda. Pacific-Basin Finance Journal.

Lu, K, Bai, Y, \& Wang, Y. (2011, August). Study on the relationship between emotional intelligence and employee performance. In 2011 International Conference on Management and Service Science (pp. 1-4). IEEE.

Lusardi, A, \& Mitchelli, O. S. (2007). Financial literacy and retirement preparedness: Evidence and implications for financial education. Business economics, 42(1), 35-44.

Markowitz, H. (1952). The utility of wealth. Journal of political Economy, 60(2), 151-158.

Mayer, J. D, \& Salovey, P. (1997). What is emotional intelligence. Emotional development and emotional intelligence: Educational implications, 3, 31.

Mayer, J. D, Caruso, D. R, \& Salovey, P. (1999). Emotional intelligence meets traditional standards for an intelligence. Intelligence, 27(4), 267-298.

Odean, T. (1998). Are investors reluctant to realize their losses?. The Journal of finance, 53(5), 1775-1798.

Olsen, R. A. (2008). Cognitive dissonance: the problem facing behavioral finance.

Petrides, K. V, \& Furnham, A. (2000). On the dimensional structure of emotional intelligence. Personality and individual differences, 29(2), 313-320.

Pompian, M. M. (2006). Behavioral finance and wealth management. How to build optimalportfoliosforprivate clients, 28.

Quinn, J. F, \& Wilemon, D. (2009, August). Emotional intelligence as a facilitator of project leader effectiveness. In PICMET'09-2009 Portland International Conference on Management of Engineering \& Technology (pp. 1267-1275). IEEE..

Rowold, J. (2005). Multifactor leadership questionnaire. Psychometric properties of the German translation by Jens Rowold. Redwood City: Mind Garden. 
Rutkauskas, A. \& Stasytyte, V. (2008). Stratification of stocks profitabilities-the framework for investor's possibilities research in the market. Intelektiné ekonomika, (1).

Salovey, P, \& Mayer, J. D. (1990). Emotional intelligence. Imagination, cognition and personality, 9(3), 185-211.

Sanfey, A. G, Rilling, J. K, Aronson, J. A, Nystrom, L. E, \& Cohen, J. D. (2003). The neural basis of economic decision-making in the ultimatum game. Science, 300(5626), 1755-1758.

Sanglier, J. J, Haag, H, Huck, T. A, \& Fehr, T. (1996). Section Review; Anti-infectives: Review of actinomycetes compounds 1990-1995. Expert opinion on investigational drugs, 5(2), 207-223.

Schutte, N. S, Malouff, J. M, Hall, L. E, Haggerty, D. J, Cooper, J. T, Golden, C. J, \& Dornheim, L. (1998). Development and validation of a measure of emotional intelligence. Personality and individual differences, 25(2), 167-177.

Scott-Ladd, B, \& Chan, C. C. (2004). Emotional intelligence and participation in decision-making: strategies for promoting organizational learning and change. Strategic Change, 13(2), 95-105.

Sekaran, U, \& Bougie, R. (2019). Research methods for business: A skill building approach. john wiley \& sons.

Shefrin, H. (2007). How the disposition effect and momentum impact investment professionals. Journal of Investment Consulting, 8(2), 68-79.

Shefrin, H. (2010). Behavioralizing finance. Now Publishers Inc.

Shleifer, A. and Summers, L.H, (1990). The noise trader approach to finance, Journal ofEconomic Perspectives 4, pp.19-33.

Simon, M, Houghton, S. M, \& Aquino, K. (2000). Cognitive biases, risk perception, and venture formation: How individuals decide to start companies. Journal of business venturing, 15(2), 113-134.

Statman, M. (2006). Socially responsible indexes. The Journal of Portfolio Management, 32(3), 100-109.

Toma, F. M. (2015). Behavioral biases of the investment decisions of Romanian investorson the Bucharest stock exchange. Procedia Economics and Finance, 32, 200207. 
Van der Zee, K, Thijs, M, \& Schakel, L. (2002). The relationship of emotional intelligence with academic intelligence and the Big Five. European journal of personality, 16(2), 103-125.

Zaidi, F. B, \& Tauni, M. Z. (2012). Influence of investor's personality traits and demographics on overconfidence bias. Institute of Interdisciplinary Business Research, 4(6), 730-746. 